\title{
Krzysztof KOWALSKI
}

Jagiellonian University in Kraków

krzysztof.1.kowalski@uj.edu.pl

\section{THE EUROPEANIZATION \\ OF THE CEMETERIES OF WORLD WAR I IN WEST GALICIA}

\section{IN SEARCH OF TRANSNATIONAL HEROISM AND SACRIFICE}

ABSTRACT Focusing primarily on the Łużna-Pustki military cemetery constructed by the Austro-Hungarian army on the Eastern Front after the Battle of Gorlice, also known as the 'Little Verdun' (2-5 May 1915), the article deals with the memory of World War I and its use in local, national (Polish) and European contexts. The text shows the history of this lieu de mémoire: its creation, cultural and artistic contexts, and ultimate slide into oblivion during the interwar period and after World War II, before a resurrection in interest in Poland at the turn of the $21^{\text {st }}$ century. Taking into consideration Europeanization processes, the author shows how tangible remnants of World War I are brought into the limelight within European frames of reference and discusses the consequences of this discursive reinterpretation of the Łużna-Pustki military cemetery, awarded a European Heritage Label in 2016.

Key words: World War I, cemeteries, lieux de mémoire, discourse, Europeanization

World War I enjoys a particular significance for Poles since, after 123 years of the Partitions, ${ }^{1}$ the conflict restored the independence which had been lost in 1795 . The

Three Partitions saw the division of the territory of the Polish Republic, in which the following neighbouring countries took part: Russia, Prussia and Austria (1772); Russia and Prussia (1793) and, finally, Russia, Prussia and Austria (1795). From 1795 to 1918, Poland ceased to exist as an independent state. 
war which had broken out in 1914 placed the armies of the Partitions on opposing sides and finally provided Poland with the means to regain its independence (1918). In striving to do so, Poles often fought in the uniforms of the Partition powers and their graves may be found in war cemeteries on the fronts of all sides of the conflict, often on opposing sides in the same battle. Apart from the heroic, national and independence threads of the conflict, the heritage of World War I has largely been forgotten in Poland and sometimes even intentionally discarded, especially when and where it was seen as belonging to the empires which, happily for Poles, ceased to exist as a result of the conflict.

In this context, the cemeteries of West Galicia which were built by the Austro-Hungarian army on the Eastern Front are remarkable in many respects. ${ }^{2}$ They are intriguing spaces as they comprise a group of 401 cemeteries of varying sizes scattered across the south-eastern provinces of Poland. In addition, they are remarkable for the symbolic openness of their creators since they were built not only for 'our' heroes (the soldiers of the Austro-Hungarian and German armies), but also the fallen of the defeated Russian army.

This article, making reference to the literature on the subject, illustrates the context of the creation of war cemeteries in West Galicia and particularly the case of no. 123 in Łużna-Pustki. It takes into account the shifting nature of the armies on the Eastern Front of World War I, the Battle of Gorlice ${ }^{3}$ and the creation of the IX ${ }^{\text {th }}$ War Graves Division at the War Ministry in Vienna ${ }^{4}$ which was responsible for the building of all of the military necropolises in West Galicia between 1915-1918. However, the panorama of historical events is not the essence of this text, merely its basis. There is a much broader discussion of the transformation that the symbolic dimension of these wartime necropolises (especially no. 123 in Łużna-Pustki) underwent as a result of the political alliance of this lieu de mémoire with successive national ideologies and their European successors.

Following the end of World War I and the collapse of the Austro-Hungarian Empire, this planned imperial landscape of victory, heroism and praise ${ }^{5}$ found itself in the territory of the newly reborn Poland which understandably approached the remembrance of the fallen soldiers of the partition armies with considerable reserve. They were forgotten and the cemeteries began to fall into ruins. The tremendous sacrifice of World War II contributed further to the obscurity of the fallen heroes of the Great War

2 I would like to stress that this article refers to war cemeteries located in West Galicia (a former province of the Austro-Hungarian Empire) which is now to be found in southeastern Poland.

3 The name of this battle is sometimes framed differently in English - the Battle of Dunajetz.

4 The translation of the term 'the IX ${ }^{\text {th }}$ War Graves Division' is taken from: J. Schubert, "Organizacja grobownictwa wojennego w Monarchii Austro-Węgierskiej. Dziewiąty Wydział Grobów Wojennych (Kriegsgräber-Abteilung) przy Ministerstwie Wojny - powstanie i działalność w latach 1915-1918. Organization and Structure of Wartime Cemeteries in Austro-Hungarian Monarchy. The IX War Graves Division (Kriegsgräber-Abteilung) at the War Ministry in Vienna in the Years 1915-1918", Architektura. Czasopismo Techniczne. Architecture. Technical Transactions, no. 13 (2009), pp. 169-200.

5 Comp.: R. Frodyma, Cmentarze wojskowe z okresu I wojny światowej w rejonie Beskidu Niskiego i Pogórza, Warszawa 1989, pp. 9-10. 
and Polish historical policy after 1945 was not interested in cemeteries which held 'foreign' heroes. Without the necessary protection, they fell victim to vandalism and the passing of time. Necropolises fell into ruin and were devoured by forests. The inhabitants of nearby villages frequently regarded them as free sources building material and degradation set in.

The situation began to change in the 1970s and 80s with the increased interest in the war cemeteries of World War I and they began to be noticed by interested locals and tourists alike. An expression of the growing interest in them and their exploitation was the preparation of the application by the local authority of Łużna and the Małopolska Provincial Office $(2015)^{6}$ for a European Heritage Label for war cemetery no. 123 in Łużna-Pustki in 2016 (the unveiling of the EHL took place on 21 April 2017). This is the last stage in the turbulent history of this necropolis and began the construction of this transnational complex of cemeteries as a lieu de mémoire héroique of the AustroHungarian Empire. It ended with a prestigious European award, received by those who are not 'the direct heirs' of this legacy. In this context one may justifiably ask how and in what sense this 'foreign', adopted heritage helps to construct European heritage and, furthermore, what happens when this discovered and adopted 'foreign' heritage is interpreted by 'us' in the context of European values. In a general sense of reflections on European heritage one may say that all of the transformations and changes that this local site underwent belong to the imaginarium of the supranational European community. This, in turn, raises another question: which historical narrative of the past of the cemetery will become the official one and which will become subsumed? From the considerations of Glen Jordan and Chris Weedon, one may ask the further question of which historical narrative concerning this place will be told/displayed and which will be silence/hidden? What will be remembered in the future and what will be forgotten? What and who will be used and what will be rejected? ${ }^{7}$

6 See: the application made to the Ministry of Culture and National Heritage and by the Department of the Conservation of Monuments of Kraków and National Heritage, Małopolska Provincial Office in Kraków and the local authority of Łużna. Comp.: interview with Joanna Florkiewicz-Kamieniarczyk, director, Department of the Conservation of Monuments of Kraków and National Heritage, Małopolska Provincial Office in Kraków, 4 April 2016; and the interview with Kazimierz Krok, head of the Łużna local authority, 7 April 2017.

7 G. Jordan, C. Weedon, Cultural Politics. Class, Gender, Race and the Postmodern World, Oxford 1995, p. 4. 
Fig.1. Cover of the brochure prepared by the Local Authority of Łużna to mark the award of the European Heritage Label

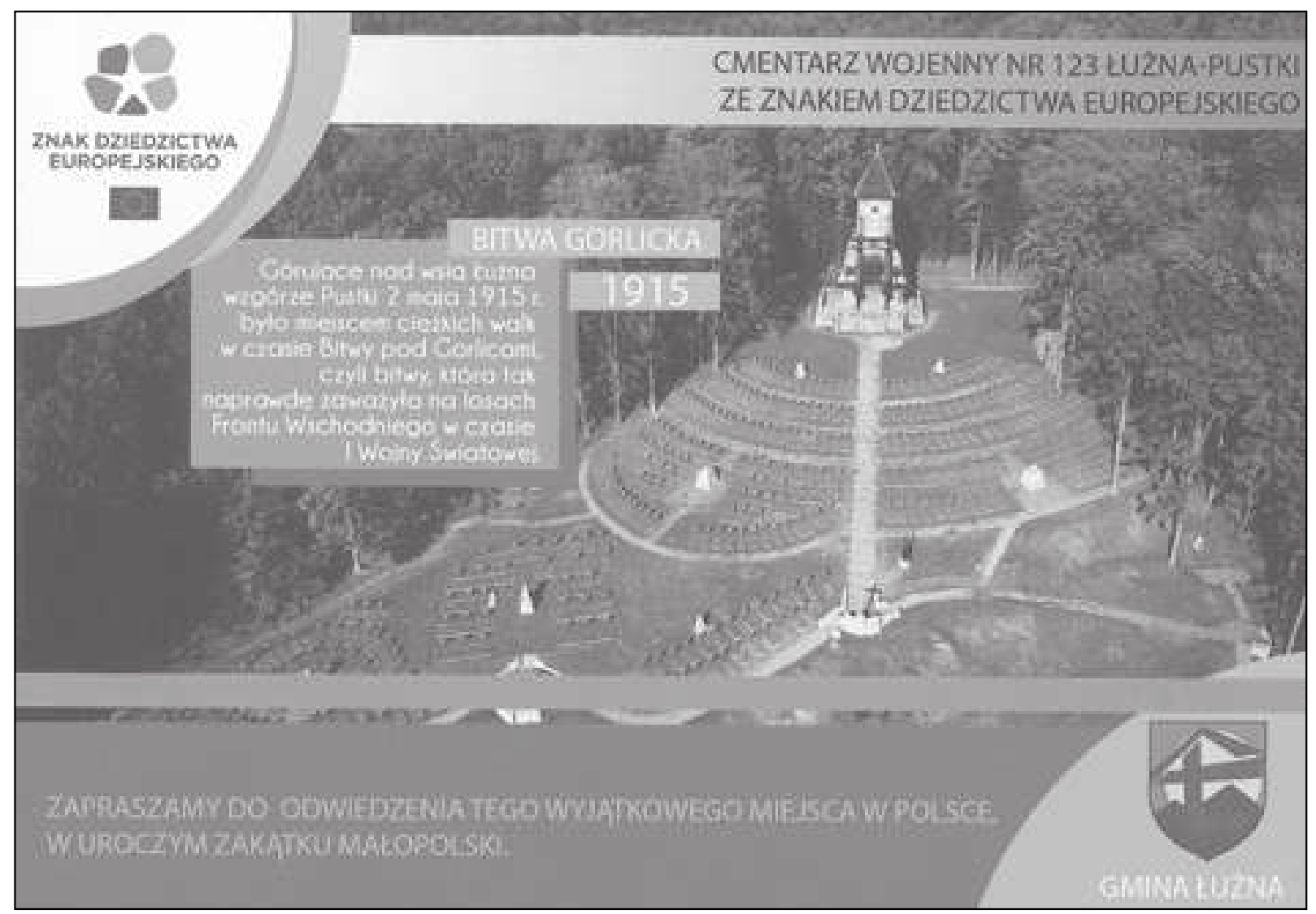

(c) photo: A. Ziobrowski, T. Machowski, D. Bugno, P. Sekuła; graphic design: T. Machowski, D. Bugno (C) Eużna Commune Office

In other words, the article portrays the symbolic changes which cemetery no. 123 underwent, beginning as an Austro-Hungarian place of remembrance, through its Polish rejection in the interwar years and its disappearance after World War II. The present, final stage in its semiotic transformation is the alliance of the Eużna-Pustki place of remembrance with European values, a result of which is its potential exploitation of this lieu de mémoire to help build a supranational and European imaginarium. The processes of Europeanization at play here utilise the ecumenical character of this place but the resulting continuity between national interpretations and their European counterpart is marked by the silencing of certain interpretations and the strengthening of others.

\section{THE SITUATION ON THE EASTERN FRONT (1914-1915)}

Following the outbreak of World War I (28 July 1914), four fronts emerged in Europe - the Western, the Southern, the Eastern and the Balkan. Aligned along them were the powers of the Entente against the Central Powers. 
The opening of the Eastern Front began on the territory of East Prussia with the Battle of Stallupönen (17 August 1914), where the German army triumphed over the forces of the Russian Empire. However, just 3 days later at the Battle of Gumbinnen, the scales shifted in favour of the Russians (20 August 1914). This victory, however, did not prevent the armies of the Tsar from suffering a crushing defeat at the Battle of Tannenberg (17 August - 2 September 1914). ${ }^{8}$ As a result of this spectacular defeat, the Russian army fell apart and its offensive ground to a halt. The situation was different on the central and southern parts of the Eastern Front.

In what is now southern Poland - then West Galicia, a part of the Austro-Hungarian Empire - the fight continued and increasingly favoured the armies of Nicholas II. Aside from the first few victories of the Austro-Hungarian Empire over the Russians (Kraśnik, 23-25 August 1914; Komorów, 26 August - 2 October 1914), the Russians captured Lviv, the capital of Galicia (3 October 1914). ${ }^{9}$ Such was the fear of the total defeat of the Austro-Hungarian army at the time that it led the commanding general, Franz Conrad von Hötzendorf, to give the order to retreat to a line along the Carpathian Mountains. As a result, the armies of the Tsar swiftly advanced across the whole of Galicia, shifting the front considerably to the west. The Russians laid siege to the Fortress of Przemyśl (5 November 1914), which finally fell to Russian forces on 23 March 1915. ${ }^{10}$ The Russians then began to attack the Fortress of Kraków ${ }^{11}$ and the Russian forces in the central part of the front began to threaten Berlin and Budapest. ${ }^{12}$

Following the Eapanów-Limanowa operation (2-12 December 1914) the front stabilised and a considerable swathe of Galicia was recovered from the Russians. From this point until May 1915, there were no major changes on either side, with a war of attrition setting in. It was only after the Battle of Gorlice (2-5 May 1915) that the character of the front changed again. A massed Austrian artillery attack on the Russian positions around Gorlice began on 2 May 1915. Particularly fierce fighting was around the

8 More information on the Galician campaign in 1914-1915 may be found in the following works: T.A. Olszański (ed.), Pierwsza wojna światowa w Karpatach, Warszawa 1985; M. Klimecki, Gorlice 1915, Warszawa 1991; D. Jordan, M.S. Neiberg, Front Wschodni 1914-1920. Od Tannenbergu do wojny polsko-bolszewickiej, transl. by J. Kozłowski, Poznań 2010; R.L. DiNardo, Przetom. Bitwa pod Gorlicami-Tarnowem 1915, transl. by J. Szkudliński, Poznań 2012. Comp.: J. Pajewski, Pierwsza wojna światowa 1914-1918, Warszawa 2004, p. 328; D. Jordan, Batkany, Wtochy i Afryka 1914-1918. Od Sarajewa do Piawy i Jeziora Tanganika, transl. by J. Szkudliński, Poznań 2011, pp. 113-114. See also: D.E. Showalter, Tannenberg 1914. Zderzenie imperiów, transl. by R. Dymek, Białystok 2005; E.D. Erickson, Gallipoli i Bliski Wschód 1914-1918. Od Dardaneli do Mezopotamii, transl. by J. Kozłowski, Poznań 2011, p. 25.

9 The first movements on the Eastern and Western Fronts are described in: J. Łaptos, J. Solarz, M. Zgórniak, Wielkie wojny XX wieku (1914-1945), Warszawa 2006, especially the chapter entitled: "Pierwsze miesiące 1915 r. na frontach zachodnim i wschodnim".

10 The Austro-Hungarian and German forces recovered the fortress on 3 June 1915.

11 On the World War I cemeteries in the Fortress of Kraków, see: B. Nykiel, "Cmentarze wojenne Twierdzy Kraków z okresu I wojny światowej”, in W. Frazik et al. (eds.), Przez dwa stulecia XIX i XX w. Studia historyczne ofiarowane prof. Wactawowi Felczakowi, Kraków 1993.

12 J. Schubert, Austriackie cmentarze wojenne w Galicji z lat 1914-1918, Kraków 1992, pp. 8-9. 
Pustki heights, which had considerable strategic significance and were regarded as the key to the Russian positions. Particularly fierce fighting took place around the Prustki heights which enjoyed considerable strategic significance. They were described as the key to the Russian positions. They were defended by the $31^{\text {st }}$ Russian Infantry Division who fortified the position, putting up wire and digging lines of trenches. The summit was seized after fierce fighting by the $12^{\text {th }}$ 'Krako'w' Infantry Division which was made up of Galician privates [...] the assault on the lines came at great cost but it was taken nonetheless. After hostilities ceased, it became one of the largest Galician cemeteries, containing the bodies of 1,200 soldiers of all armies. ${ }^{13}$ Ultimately, the Battle of Gorlice was a prelude to many weeks of Austro-Hungarian and German advances to the east, with the Russians giving up all of the territory that it had gained just a few months earlier. ${ }^{14}$

\section{AN OUTLINE OF THE HISTORY, ORGANIZATION AND ACTIVITY OF THE IX ${ }^{\mathrm{TH}}$ WAR GRAVES DIVISION}

The victory of the Central Powers on the Eastern Front came at great cost to both sides. Before the Battle of Gorlice, the landscape of the Beskid Mountains was riven by lines of trenches and the offensive destroyed whole villages and left towns in ruins. After the passing of the front through West Galicia, the decaying bodies of the fallen soldiers of all the armies lay on the fields. A few months after the Battle of Gorlice, it became necessary to rearrange battlefields, to exhume bodies from temporary graves, to build final graves, to prevent the outbreaks of epidemics, and to give the peasants a land to return to and grow crops on. ${ }^{15}$

The IX ${ }^{\text {th }}$ War Graves Division was created on 3 November 1915 by the Ministry of War in Vienna (Germ. Kriegsgräber-Abteilung, KGA), with a task which would have been difficult to perform even in times of peace. It had to coordinate all of the exhumation, identification and designing, building and care of cemeteries used as symbols of war. ${ }^{16}$ This titanic task encompassed an area of $100,000 \mathrm{~km}^{2}$ of West Galicia. It was done by our less able soldiers and a large number of $\mathrm{POW},{ }^{17}$ including Italians famed for their stonework (sent from the southern front) and Russians who were known to be

13 A. Partridge, Otwórzcie bramy pamięci. Cmentarze wojenne z lat 1914-1918 w Matopolsce, Kraków 2005, pp. 26-27. Oktawian Duda gives an alternative date for its establishment namely the $3^{\text {rd }}$ of December 1915. O. Duda, Cmentarze w Galicji Zachodniej 1914-1918, Warszawa 1995, p. 31.

14 A. Partridge, Otwórzcie bramy pamięci..., ch. "Galicja Zachodnia w latach 1914-1918”, pp. 14-29.

15 R. Broch, H. Hauptmann, Zachodniogalicyjskie groby bohaterów z lat wojny światowej 1914-1915, transl. by H. Sznytka, ed. by J.J.P. Dragomir, Tarnów 1994 [Die Westgalizischen Heldengräber aus den Jahren des Weltkrieges 1914-1915, Wien 1918], p. 2.

16 A. Partridge, Otwórzcie bramy pamięci..., p. 34. It should be noted that from April 1916 KGA was affiliated with the German War Graves Division (Deutsche Kriegsgräber-Abteilung). As Oktawian Duda has stated, no documents detailing the form of their cooperation has survived. O. Duda, Cmentarze w Galicji Zachodniej..., p. 40. Comp.: J. Schubert, Autriackie cmentarze wojenne..., p. 13.

17 R. Broch, H. Hauptmann, Zachodniogalicyjskie groby bohaterów..., p. 2. 
skilled carpenters. ${ }^{18}$ In addition, the soldiers were aided in their efforts by civilian employees of the KGA and locals. ${ }^{19}$

Rudolf Broch was made the commander of the KGA and Hans Hauptmann the chief designer. ${ }^{20} \mathrm{~A}$ joint publication about the West Galicia cemeteries published in 1918, they both wrote about the venture that above all we were grateful for their service to the Fatherland, to Justice, the Conscience of the World and, finally, each of us. In their work, Broch and Hauptmann further wrote that they were overwhelmed by the glorious deaths of the soldiers and it was this awareness and feeling of gratitude which found its best expression in the cemeteries where we had prepared a final resting place for our fallen heroes. ${ }^{21}$ They gave their work a more universal character with the claim that [...] the Fatherland has striven to create, on the scale of the modern world, an appropriate and dignified resting place for its Sons who have fallen on the field of battle and honour [...] the love of the whole of Austro-Hungary created this cemetery, the respect of the whole of Austro-Hungary will hold a sword and shield over it for all time. ${ }^{22}$

Thanks to the tremendous expenditure of both resources and human effort, as Agnieszka Partridge notes, in the space of two years, from 1916 to 1918, and at a record breaking speed, over 400 cemeteries and memorials were created. The last work in the $11^{\text {th }}$ cemetery region was done in November 1918, when it was already clear that the Empire lay in ruins. ${ }^{23}$ The cemeteries were finished when the fall of the Central Powers was already predestined and unavoidable. The desire to perpetuate the memory of the fallen soldiers of the Empire was meant to triumph over the result of the conflict.

The area covered by the IX ${ }^{\text {th }}$ War Graves Division was tremendous as it encompassed the matter of wart graves across the whole [Austro-Hungarian] Kingdom and its occupied territories. ${ }^{24}$ Three military zones were created in Galicia, with headquarters in Kraków (the 'West Galicia' zone), Przemyśl (the 'Central Galicia' zone) and Lviv (the 'East Galicia' zone). ${ }^{25}$ Each of them had one particularly important and representative cemetery and in the Kraków zone, that was no. 123 in Eużna-Pustki.

The KGA sought out temporary cemeteries and burials, exhuming and identifying the bodies. Together with the identifying group, architects, sculptors, photographers and artistic directors moved across the battlefields. They assessed the location and arrangement

18 J. Schubert, Austriackie cmentarze wojenne..., p. 17.

19 Frodyma wrote - alluding to the works of Broch and Hauptmann - that the KGA received more than 4,000 workers, of whom nearly 3,000 were prisoners of war, mainly Italians and Russians. J. Schubert, Autriackie cmentarze wojenne..., p. 17.

J.J.P. Drogomir, "Wstęp do wydania polskiego", in R. Broch, H. Hauptmann, Zachodniogalicyjskie groby bohaterów..., pp. VII-VIII.

R. Broch, H. Hauptmann, Zachodniogalicyjskie groby bohaterów..., p. 3.

22 Ibid., p. 8. Comp.: J. Winter, Sites of Memory, Sites of Mourning. The Great War in European Cultural History, Cambridge 2008.

23 A. Partridge, Otwórzcie bramy pamięci..., p. 28.

24 J. Schubert, Austriackie cmentarze wojenne..., p. 13.

25 O. Duda, Cmentarze w Galicji Zachodniej..., p. 32. See: R. Frodyma, Cmentarze wojskowe..., p. 9. 
of the temporary graves and sought out places for new cemeteries [...] the photographers took a huge number of documentary and landscape photographs. Subsequently, preliminary projects were prepared. [...] Then came the time to implement them. A team of army engineers went to work, laying out the area of the future cemetery and the road leading to it. Work was done in quarries and lumber camps to collect the necessary material, foundry work took place. ${ }^{26}$

During World War I, a new form of cemetery art arose. ${ }^{27}$ This was the military cemetery, symbolically appealing to the ethos of the soldier-hero and the holiness attained by their sacrifice on the battlefield. ${ }^{28}$ It is best expressed by the line of Horace, Dulce et decorum est pro patria mori. ${ }^{29}$ In this spirit, the cemeteries built in World War I on both the Western and Eastern fronts did not abound in details but rather emphasised the military severity and gravity of the sacrifice made. ${ }^{30}$

The solutions applied in Galicia had a unique character and the analogical approach applied in the cemeteries of the Western Front was somewhat different. It must be emphasised that what distinguishes cemetery no. 123 in the European context is that in the Galician cemetery were interred not only the soldiers of the Central Powers but also those of Russia joined them in their eternal rest. The heroes were not divided into 'ours' and 'theirs', they were all treated with the same due respect. ${ }^{31}$ What is more, it also transpired (e.g. at the dedication of the cemetery in Gorlice) that an 'official' delegation of Russian regiments took part, from among the ranks of POWs and who had earlier worked in building the cemetery. ${ }^{32}$

This was a phenomenon that one did not encounter on the Western Front. There one could find just a handful of common cemeteries containing the fallen of the French and British armies, the Allies. Never, however, were the dead of the opposing armies laid to rest together. It is hard to find an example in history of the treatment of yesterday's

26 J. Schubert, Austriackie cmentarze wojenne..., p. 16. Some of the graves of the Austro-Hungarian and German soldiers have nameplates thanks to the so-called 'tags' that allowed for the accurate identification of the buried. The Russian army did exactly the opposite. Not only did the soldiers not have such identifiers, but most of the graves being built were of a mass character, and the corpses were deprived of all signs of identification. The following registers were introduced: a) alphabetical order by surname, b) by the place of the cemetery, and c) by unit.

27 A. Partridge, Otwórzcie bramy pamięci..., p. 35. Comp. the chapter: "Projektowanie i budowa cmentarzy, organizacja robót i transport materiałów”, in O. Duda, Cmentarze w Galicji Zachodniej..., pp. 44-48.

28 See: J. Winter, Sites of Memory... Comp.: E. Kantorowicz, Mourir pour la patrie et autres textes, Paris 1984; S. Czarnowski, Kult bohaterów i jego spoteczne podtoże. Święty Patryk - bohater narodowy Irlandii, transl. by A. Glinczanka, Warszawa 1956; M. Ossowska, Ethos rycerski i jego odmiany, Warszawa 1986, pp. 7-20.

29 Horace, Odes III, 2.

30 A. Partridge, Otwórzcie bramy pamięci..., p. 35. Comp. with the chapter: "Projektowanie i budowa cmentarzy..., pp. 44-48.

31 The ecumenical dimension was stressed very strongly in the application for the European Heritage Label.

32 O. Duda, Cmentarze w Galicji Zachodniej..., p. 40. 
enemies with a similar degree of humanism, raising monuments to them, protecting their graves from being forgotten together with those of their own fallen. ${ }^{33}$

The supranational, multicultural and multi-religious character of the Galician necropolises is underscored by the fact that in the majority of the cemeteries (95\%) the fallen of all three fighting armies are found together, those of different nationalities and faiths (with the exception of Jews), with just 12 cemeteries for only the soldiers of the Russian army and 14 separate ones for fallen Jews. ${ }^{34}$ The army, regimental, and national affiliations were distinguished, and the design of the grave crosses determined whether the soldier was Christian, Muslim, or Jewish. For even greater precision, a Latin cross was used for both Catholics and Protestants, with an Orthodox cross (with an extra arm) for Orthodox Christians. Muslims were given headstones, and Jews - in accordance with religious observance - in their own cemeteries, often built especially for them. ${ }^{35}$

\section{THE SLAVIC ARTISTIC DIMENSION AND OTHER STYLISTIC ELEMENTS PRESENT IN THE CEMETERIES}

The artistic aspect of the cemeteries was intended to reinforce their moral, supranational, multicultural and multi-religious character. They used motifs taken from Antiquity, the Renaissance, Romanticism and Classicism, motifs which allowed the creation of a cemetery complex in Matopolska which it would be impossible to find elsewhere. ${ }^{36}$

Each of the artists working for KGA had their own style. Thus whilst in the work of one might find the symbols of war (swords, soldiers caps), others chose a monumental style or appealed to folk, local or non-Slavic traditions. ${ }^{37}$ As a result, the architecture of the cemetery is full of borrowings and more or less evident connections. In the projects there appeared elements of individual style: visible in the references to former architec-

33 J.J.P. Drogomir, “Wstęp...”, p. IV.

34 O. Duda, Cmentarze w Galicji Zachodniej..., p. 42.

35 Judaism prohibits the burial of Jews in a Christian cemetery. As a result, 15 Jewish cemeteries were created (the largest and located alone is Zakliczyn no. 283). It sometimes transpired, however, that in spite of the prohibition, some Jewish soldiers were interred in Christian cemeteries. Comp.: M. Łopata, "Groby żydowskich żołnierzy Wielkiej Wojny w Galicji”, in M. Dziedziak (ed.), Znaki pamięci. Materiaty z konferencji naukowej, Gorlice 27.10.2007, Gorlice 2007, pp. 5-27. Jews were buried together, in common graves, with the fallen Jewish soldiers of both sides laid to rest next to one another; ibid., p. 16. Apart from the work of the War Graves Division in West Galicia, well maintained Jewish military cemeteries can be found in Nowy Targ, Wadowice, Bielsko-Biala, Cieszyn, Frysztak (Karwin) and Ostrava. Ibid., p. 19.

36 A. Partridge, Otwórzcie bramy pamięci..., p. 28. Agnieszka Partridge writes about many of the formal elements utilised by the creators of the cemeteries: urns, sarcophagi, dedication elements (e.g. charms), tablets with the names of the fallen soldiers, crosses etc.

37 On the subject of the different styles, elements and symbolism applied in the cemeteries of West Galicia, see: ibid., ch. "Symbolika galicyjskich cmentarzy wojennych", pp. 70-215. 
ture - mainly Romanesque, Renaissance and Baroque - created in the spirit of modernism and from the flowing lines of Secessionism. ${ }^{38}$

Particularly well known builders of Galician cemeteries were Dušan Jurkovič and Jan Szczepkowski, but in differing ways Wojciech Kossak, Hans Mayr, Henryk Uziębło many others cooperated with the KGA. ${ }^{39}$

The most beautiful wooden chapels and cemetery elements were designed by Dušan Jurkovič, known as the 'poet in wood'. Chapels and Slavic gontynas ${ }^{40}$ became his calling card. They were connected to Slavic elements and in a clear manner utilised the Carpathian architectural style which can be seen in many Carpathian churches, Catholic and Orthodox alike. ${ }^{41}$ In the 'gontynas', 'kącinas' and 'stołpas', he found a national symbolism, an old Slavic impulse which allowed him to freely express this existential content. ${ }^{42}$ What is more, some of his projects were regarded as being too Slavic in their character and were amended or even did not make it past the tender stage judged by the artistic commission of the KGA in Kraków. ${ }^{43}$

Jan Szczepkowski was also considered to be old and proto-Slavic, ${ }^{44}$ and who, like Jurkovič, sought inspiration in folk traditions, including their buildings. The influence of the emerging Zakopane style on his cemeteries is unmistakable. His style was considered homely, close to tradition, folk art, nature. ${ }^{45}$

The attitude of Poles - especially the Kraków elite - to the cemeteries was negative, rejected for both ideological and artistic reasons. They were criticised for the alien, Prus-

38 K. Chrudzimska-Uhera, "O dylematach Polaka, artysty, żołnierza. Jan Szczepkowski jako projektant cmentarzy I wojny światowej”, in M. Łopata, K. Ruszała (eds.), Znakipamięci IV - w 95. rocznicę bitwy gorlickiej. Materiaty z konferencji, Gorlice 2011, p. 52.

39 O. Duda, Cmentarze w Galicji Zachodniej..., ch. “Twórcy cmentarzy”, pp. 52-58.

40 The gontyna (also known as a kontyna or kacina) was a form of pagan temple found in areas that previously been occupied by the Old Prussians, Slavs and Lithuanians. See: "gontyna", in Stownik jezyka polskiego, at <https://sjp.pl/gontyna >, 8 April 2017.

41 Orthodox elements may be found in Jurkovič himself, whose opinion of the cemetery no. 51 is described by A. Kroh, "Dušan Jurkovič a styl zakopiański", in Cmentarze z I wojny światowej na Podkarpaciu. Materiaty z sesji krajoznawczej, Wysowa 23-25 października 1987, Warszawa 1989, p. 13.

42 A. Partridge, Otwórzcie bramy pamięci..., p. 149. Sometimes, the cemeteries of this creator have even been compared to human figures. To date, some of the unrealized cemetery designs of this artist have been preserved, preserving their stylistic references. See: M. Dziedziak, "Niezrealizowane projekty cmentarzy wojennych Dušana Jurkoviča w Beskidzie Niskim”, in idem (ed.), Znakipamięci..., pp. 27-40.

43 On the alterations to projects deemed to be too Slavic or religous, see: K. Ruszała, "Zachodniogalicyjskie cmentarze na pocztówkach wydanych przez Oddział Grobownictwa Wojennego. Projekty i ich realizacja”, in M. Dziedziak (ed.), Znaki pamięci..., p. 49.

$44 \quad$ K. Chrudzimska-Uhera, “O dylematach...”, p. 53.

45 Ibid., p. 49. Katarzyna Chrudzimska-Uhera writes that at the time of the construction of the Galician cemeteries at the beginning of the $20^{\text {th }}$ century, the search for a distinct, Polish national style was strongly being sought and which was reflected in art, crafts and architecture. This synergy, embodied in the national framework, was meant to express and at the same time strengthen Poland's national identity. Polishness, expressed in native and local tradition, was also sought in medieval and Romantic patterns. In addition, folk art - especially from the Podhale region - became the basis for the national style. And it is Podhale and its folk borrowings which are visible in the cemeteries built by Szczepkowski. 
sian style of the necropolises, of polluting the landscape, of having nothing to do with Polish culture and art. The completed cemeteries were accused of a lack of taste, being termed and charged with being: stone-faced terrors, freaks of concrete and twisted iron and that their 'banality and ugliness' was a scar on the Polish landscape. Even their removal was mooted. ${ }^{46}$

Furthermore, the plans were considered to be alien to the Slavic soul, and they were called Teutonic, as if they were aesthetically brutal and political enemies. ${ }^{47}$ The Polish artists involved in the construction of the cemeteries were stigmatized and rejected..$^{48}$ An atmosphere arose in which the destruction of the cemeteries became distinctly possible. As Agnieszka Partridge wrote, the first acts of vandalism on graves and cemeteries occurred two years after the war, already in 1920. Later, there were cases of destruction even in those cemeteries where legionaries were buried. ${ }^{49}$

Consequently, in the interwar period and after World War II, the cooperation of Polish artists with the Austrian authorities in the construction of cemeteries in West Galicia was not necessarily a cause for personal pride. Katarzyna Chrudzimska-Uhera points out that the subject of Szczepkowski's involvement in KGA works was, as one might suspect, initially silent in two biographies of the artist, the first of which appeared in the interwar period and the second in the Polish People's Republic. The cemetery-building aspect did not match the image of the co-creator of the Polish national style. ${ }^{50}$

\section{PILGRIMAGES IN THE INTERWAR PERIOD}

In Western Europe, the construction of large military necropolises led to the growth in pilgrimages to soldiers' graves. Individuals, families and associations were involved. ${ }^{51} \mathrm{An}$ analogous - albeit much more limited - phenomenon was observed in Poland, where the cemeteries were well marked and easily accessible. They were visited by Czechs,

46 Ibid., p. 49. Chrudzimska-Uhera refers to particualr opinions expressed in publications of the period: Nagrobki, Kraków 1916, pp. 3, 55; T. Szydłowski, Ruiny Polski, Kraków 1919, pp. 187-190, R. Feliński, "Pomniki wojny i zmartwychwstania Polski”, Rzeczy Piękne, no. 1 (1919), p. 4; G. Kowalski, "O naszą kulturę. Uwagi o odbudowie i ratowaniu zniszczonych zabytków”, in Sprawozdanie i wydawnictwo Wydziatu Towarzystwa Opieki nad Polskimi Zabytkami Sztuki i Kultury za rok 1914 i 1915, Kraków 1916, pp. 26-27.

47 W. Kosiński, "Wstęp”, in A. Partridge, Otwórzcie bramy pamięci..., p. 9. Ibid.

49 A. Partridge, Otwórzcie bramy pamięci..., p. 268.

K. Chrudzimska-Uhera, "O dylematach..., p. 50. Broch and Hauptmann (iidem, Zachodniogalicyjskie groby bohaterów..., p. 150) show the stylistic differences of Szczepkowski in comparison to other artists working for KGA. In their view, he appeals to folk culture, underscores the role of nature in cemetery projects and their place in the landscape and their natural context. There also appears - perhaps even as a criticism - that the cemeteries designed by him appeal to a 'naïve form of folk art' (ibid., p. 150).

51 J. Winter, Sites of Memory..., particularly the chapter entitled "Communities in Mourning”. 
Hungarians and Slovakians but also by Austrians and Germans. ${ }^{52}$ This had been the desired effect which the designers of the cemeteries had in mind when they created them.

In order to make the cemeteries more attractive, KGA artists used the potential of the surrounding landscape and nature. Broch and Hauptmann believed that in the most picturesque areas of the Western Carpathians of Galicia, which were discovered by foreigners during the war, may join the ranks of Europe's most popular tourist destinations. The most notable attraction in this mountainous landscape will certainly be the many cemeteries of fallen soldiers. ${ }^{53}$

In addition, Broch and Hauptmann were driven by the conviction that the soldiers' necropolis was not only an expression of respect for the sacrifice made by the fallen, but also of the goal of patriotic pilgrimages exploring the attributes of the Beskid Niski and Pogórze region. As they recall, the work of building cemeteries was accompanied by the following thought: Take the sandals from your feet, for the land on which you stand is holy ground..$^{54}$ In this way, the landscape was sacralised together with the soldiers' graves. Around them, as they were planning them, a pilgrimage movement was developing, and most of the cemeteries were built to serve as patriotic ceremonies. It had already been the case on All Souls Day in 1915 and 1916 [...] It was anticipated that after the war these cemeteries would be visited by families and fellow pilgrims, and also become a place of pride and reflection for subsequent generations. This postulate was related to the positivistic idea of the cemetery as a historical record..$^{55}$

The paradox of history is that these necropolises, which were planned and built with such dedication, forethought and a wealth of symbolic references, began to be forgotten soon after the end of the Great War. The Austro-Hungarian Empire not only lost World War I but it also fell apart. The heroes lost their Fatherland/homelands for which they sacrificed their lives. Their sacrifice turned out to be futile.

\section{THE AFTER WAR PERIOD AND THE MAEOPOLSKA HERITAGE LIST}

After World War II, the complete lack of interest on the part of the state authorities sentenced the Eużna cemetery - as well as the other cemeteries built between 1915-1918 to ruin..$^{56}$ From the 1970 s and 80 s, an image remains in the memory of the inhabitants of Łużna of the gontyna as a place where May blessings and Rosary services were performed by priests from the local parish. At that time, the cemetery was overgrown with forest to which the necropolis owed its romantic character. Zofia Żmijowska mentions

\footnotetext{
52 A. Partridge, Otwórzcie bramy pamięci..., p. 268.

53 R. Broch, H. Hauptmann, Zachodniogalicyjskie groby bohaterów..., p. 23, in A. Partridge, Otwórzcie bramy pamięci..., p. 52.

54 R. Broch, H. Hauptmann, Zachodniogalicyjskie groby bohaterów..., p. 10.

55 A. Partridge, Otwórzcie bramy pamięci..., p. 56.

56 European Heritage Label Application Form 2015, point "Description of the site”, p. 9.
} 
that the sun light shone through him, illuminating the individual graves. This romanticism is gone today. Then [before the trees were cut] the cemetery was charming. ${ }^{57}$

From the end of World War II until the 1980s, the cemetery gradually lost the character of a soldier's necropolis, and became an 'overgrown park' where families walked on Sundays and where young people went to play truant. The role of the soldier's necropolis was clearly suspended, although - and this should not be overlooked - it was still present. The heroic fate of particular soldiers ceased to be the central element in this space. It became instead the backdrop to everyday life. Without descendants to care for it, the cemetery became a non-place - non-lieu - losing its original, funeral character. ${ }^{58}$ Society ceased to be tied to this place and its extreme liminality was reinforced by the fact that - as current inhabitants of the village maintain ${ }^{59}$ - the wooden chapel at the top had been taken over by the homeless as their abode. They also ascribed to them the fire which completely destroyed the gontyna on 29 June $1985 .{ }^{60}$

Yet paradoxically the fire which destroyed the gontyna saw the beginning of a phase in which interest arose in the cemeteries built in World War I period in West Galicia. This steady growth in interest led in 2006 (two years after Poland had joined the EU) to placing cemetery no. 123 in Łużna-Pustki on the list of objects which were the focus of the $8^{\text {th }}$ edition of the Małopolska Heritage Days (20-21 May) which are organised by the Małopolska Institute of Culture based in Kraków (MIC, Pl. Małopolski Instytut Kultury). ${ }^{61}$ A brief description of the cemetery placed in a guidebook prepared for the event claims that during the Gorlice operation, thousands of soldiers from both sides perished, amongst them many Poles. We can also read that: It is the largest Hungarian cemetery complex outside the borders of Hungary. ${ }^{62}$

The Polish aspect in the guide to cemetery no. 123 is stressed by the figure of General Tadeusz Rozadowski who prepared the artillery barrage which preceded the attack on the positions by two Polish regiments: the $56^{\text {th }}$ Wadowice Infantry Regiment and the $100^{\text {th }}$ Cieszyn Infantry Regiment. The victory [of the Austro-Hungarian army] was bought at tremendous [Polish] cost. ${ }^{63} \mathrm{John}$ Paul II also appears in the guide, not as a central figure but his sacralising presence to the site is noted. We learn that Sergeant Karol Wojtyła, the father of the Pope, took part in the assault on Pustki. This is a clearly Polish, national and Catholic element. Furthermore, the contemporary touristic at-

57 Conversation conducted with Zofia Żmijowska (20 April 2017), a Polish teacher at the school in Łużna and amateur photographer. As evidence of the romantic character of the place, Zofia Żmijowska showed her collection of photographs of the place from the 1980s. wej”, Cmentarz wojenny Nr 123 Łużna-Pustki (official website devoted to cemetery no. 123 in Łużna-Pustki), at <http://www.pustki.luzna.pl/gontyna.html>, 8 April 2017.

61 The cemetery in Eużna was placed on the list of places for the Małopolska Heritage Days in 2013.

62 B. Sanocka, VIII Matopolskie Dni Dziedzictwa Kulturowego, Kraków 2006, text without page numbers.

63

M. Augé, Non-lieux, introduction à une anthropologie de la surmodernité, Paris 1992.

This view was also ventured by Kazimierz Krok (interview 7 April 2017).

"Kaplica cmentarna (gontyna), Wzgórze Pustki w Łużnej. Dzieje historyczne - czasy I Wojny ŚwiatoIbid. 
tractiveness of the site is emphasised by the laconic description of it: the composition of the necropolis is particularly picturesque: the graves are marked by simple, wooden crosses placed amongst the trees [...] just below the summit is located an amphitheatre. Winding between the crosses and the trees are paths [...] they bring to mind a landscaped garden. ${ }^{64}$

For tourists visiting the cemetery during the Cultural Heritage Days, the Małpolska Institute of Culture prepared a plan of the cemetery in 2006 (see fig.2). This route, which tourists can complete in stages, leads from the entrance to the summit where a wooden chapel stood until $1985 . .^{65}$ The accompanying description is important, in which we learn that the construction follows the lines of existing trenches and the 'fighting of the fallen heroes.' The character of the place, which retains the memory of the tragic events of 90 years before, is emphasised by the additional information that the cemetery also shows the symbolic relation between the fallen (soldiers) with the earth upon which they fell in battle. In addition, the cemetery was designed as a 'grove for heroes'.66 This is also linked to the classical idea of 'Pro Patria Mori' by the statement that a soldier's death is not an anonymous and private matter: it is a heroic sacrifice given for the homeland. This idea is expanded upon by the claim that the cemetery was funded by the citizens of Austro-Hungary to be a monument to victory in war and the defence of the Fatherland. This formulation is linked to the inscription from the gontyna which one may find on the map: To the eternal memory of fallen heroes who met their deaths in striving to win this summit for the glory of the Fatherland. ${ }^{67}$

The map proposes a visit in the manner of one's own ahistorical participation in the events of 2 May 1915. This is akin to reliving mythical events - a mythical battle which is all the more powerful when it is done in situ. ${ }^{68} \mathrm{On}$ the plan of the cemetery, the route is enriched by a clearly biblical reference which was also referred to by Broch and Hauptmann: Take the sandals off your feet, for the place where you stand is holy ground. ${ }^{69}$ So, the modern tourist/pilgrim enters a quasi-sacral space, into the 'heroic space.' The steps of the tourist/pilgrim imitate those of the fallen heroes, and their heroic effort becomes that of the tourist. In this context, the plan states that the stages have been made in such a way that their conquest should not be a 'light' one. ${ }^{70}$

The identity of the place is a fact and brooks no argument (the place of the battle is also the cemetery which the tourist/pilgrim visits). As a result, the tourist/pilgrim climbs up, conquering the different phases of the battle which are marked by successive

64 Ibid.

65 In 2006, the gontyna was yet to be restored.

66 Map prepared by MIC for use in the war cemetery no. 123 in Eużna-Pustki during the $8^{\text {th }}$ edition of the Małopolska Heritage Days.

67 Ibid.

68 A similar effect was achieved during the ceremony to mark the unveiling of the European Heritage Label on 21 April 2017, during which a film showing the fighting on the Eastern Front on 2 May 1915 was shown.

69 Exodus 3,5.

70 Map prepared by MIC... Here should be mentioned the numerous re-enactment groups who recreate the events of the World War I period. 
Fig.2. Map prepared by the Małopolska Institute of Culture for the $8^{\text {th }}$ edition of the Małopolska Heritage Days (20-21 May 2006)

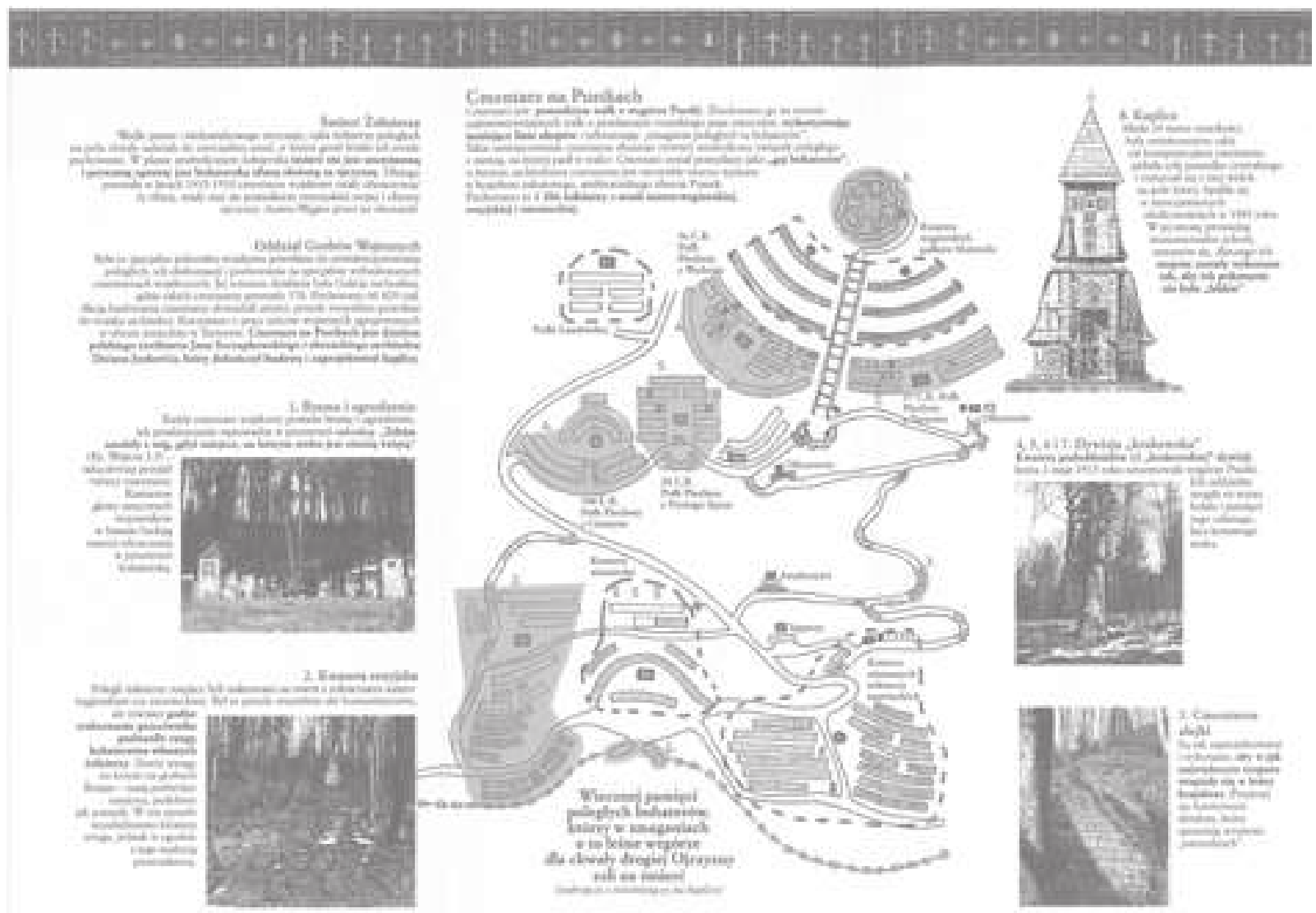

(C) Małopolska Institute of Culture

graves. In this manner they 'repeat' the assault of 2 May 1915. During the visit, historical time becomes suspended and is replaced by mythical time, by the time of heritage. This patrimonial illud tempus allows the tourist/pilgrim to touch, feel and see the past. In other words, the memory materialized in the heritage here is used as a social tool to transgress time and return to a mythical time of before, a time belonging to the fallen heroes. Following in their footsteps allows us to 'open' up a way to this patrimonial illud tempus from which it all began and in which the law that clearly distinguish good from evil have been established. ${ }^{71}$ It is not, however, a law which diminishes the vanquished at the hands of the victors but rather one which unites them and removes the barrier between the 'enemies' and the 'heroes'.

On the field of battle, the honour of a heroic death erases any army, national, cultural, religious or other affiliation. By becoming fallen heroes on the summit of Pustki, the soldiers joined a pantheon of fame which exceeds the purely national frame. As soldiers

71 This type of mythical thinking is expressed by the idea of the European Heritage Label. It is Europe starts here. 
they had names, surnames and ranks, ${ }^{72}$ but as heroes they lose their individual identity. Their individual biographies 'disappear' (Fr. disparaître), as Roland Barthes put it. ${ }^{73}$ In their place stands their collective heroism and reconciliation which - as Barthes' theory has it - overwhelms them intrusively, contextually and intentionally. History evaporates, stolen by the myth.

\section{PREPARATIONS FOR THE CENTENARY OF THE BATTLE OF GORLICE}

On 28 June 2014, almost 30 years after fire had levelled the gontyna, a ceremony was held to mark the interment of a lump of coal in the foundations to mark the rebuilding of this soldier's chapel and the whole of cemetery no. 123 on Pustki in Łużna. Work proceeded at great speed and the reconstructed building was opened on 18 October $2014 .{ }^{74} \mathrm{~A}$ new chapter in the history of the Eużna-Pustki necropolis and its presence in the historical consciousness of the inhabitants of the whole region began.

After the restoration of the cemetery chapel and before the hundredth anniversary of the Battle of Gorlice (1-2 May 2015), the local school in Łużna organised a competition devoted to historical knowledge under the slogan They passed away. They left traces. Although Poland had not been a distinct party in World War I, it was the Polish 'national' and 'patriotic' elements which were clearly expressed and historically justified in the first stages of this competition. This was also emphasised both in the competition regulations and in the questions asked to young people. ${ }^{75}$ The first stage of the competition overlooked questions on the cemetery itself in Pustki and other necropolises from World War I in the region while the second stage redressed this omission and such questions appeared. What was interesting was that the Polish, 'patriotic' and independence elements were emphasised by questions related directly to the famous song We are the First Brigade ${ }^{76}$ sung by the Polish Legion led by Józef Piłsudski. ${ }^{77}$

72 For a more precise identification see: R. Broch, H. Hauptmann, Zachodniogalicyjskie groby bohaterów... See: J.J.P. Drogomir, Polegli w Galicji Zachodniej 1914-1915 (1918). Wykazpolegtych i zmartych pochowanych na 400 cmentarzach wojskowych Galicji Zachodniej, vol. 1, Tarnów 1999.

73 R. Barthes, Mythologies, Paris 1957.

74 Informator Gminny. Eużna, no. 2 (2015), p. 11, and interview with Kazimierz Krok.

75 The first two regulations of the competition were the following: 1. Shaping the awareness and patriotic attitudes of the younger generation through the diversification and deepening of knowledge on the subject of the history of Poland and the region. 2. Strengthening the sense of national identity. From: Regulations of the Historical Knowledge Competition. 100 ${ }^{\text {th }}$ Anniversary of the Battle of Gorlice, material made available by the director of the school in Łużna, author's own collection. See also: set of competititon questions (stage I), author's own collection.

76 Regulations of the Historical Knowledge Competition. 100 $0^{\text {th }}$ Anniversary of the Battle of Gorlice... See also: set of competition questions (stage II), author's own collection.

77 Józef Piłsudski - national hero and creator of the independent Polish state (1918). 
A considerably different stress was to be found in the school photography competition (spring 2015) which was intended to shape the patriotism of the younger generation but also awaken interest in the history and culture of their own region. The subject of the pictures were to be places commemorating the events of World War I e.g. cemeteries, monuments, obelisks, grave figures, chapels and cemetery chapels..$^{78}$ As a result of these conditions, works flowed into the competition from cemeteries in the III and IV zone of the war graves. One of the most photographed objects was, of course, cemetery no. 123 in Łużna-Pustki. ${ }^{79}$

In the choice of topics and in the descriptions of the submitted pictures, one could clearly see two notions. The first clearly appealed to the national frame of reference, according to which particular graves and cemeteries were identified. In this respect, Austrian, German, Russian, Polish and Hungarian graves were to be seen. The second approach dealt with the more universal theme of the death of soldiers on the field of honour. Here, the national element is not present and the fallen heroes are an eternal guard ${ }^{80}$ to use the title of the work by Magdalena Tatko. In other words, the pantheon to which both 'common' sets of heroes is not an effect of national selection but refers to a much broader frame of reference. They are not European, however, but universal.

\section{CENTENARY CELEBRATIONS FOR THE BATTLE OF GORLICE}

During the celebrations of the centenary of the Battle of Gorlice (1-2 May 2015), a certain tension between the national (Polish) and European and even universal manner of the interpretation of these events and cemetery no. 123 became manifest. The Informator Gminny. Euzna (Eng. Local Newspaper. Euzina) came to the conclusion that the events were of a patriotic nature, to learn about the tragic period of events during World War I and to pay respects to the fallen soldiers. ${ }^{81}$ Furthermore, an expression of love to the Fatherland was the communal singing by the public of symbolic, Polish songs from the period. ${ }^{82}$ The aim of the event was to bring participants closer to the atmosphere expe-

78 Regulations of the Regional Photographic Competition. 100 ${ }^{\text {th }}$ Anniversary of the Battle of Gorlice (version for primary and junior high schools), material made available by the director of the school in Łużna, author's own collection.

79 A separate question is the stylistics of these works and the translations of their titles. Apart from the photography competition, an arts and crafts competition for primary school children was organised in which the gontyna was one of the most popular subjects chosen by the children.

80 Na wiecznej warcie, photographic work by Magdalena Tatko, class IIa, Junior High School no. 6. See also: the documentation for the photographic competition entitled "Międzygminny Konkurs Fotograficzny". 100 ${ }^{\text {th }}$ Anniversary of the Battle of Gorlice (version for primary and junior high schools), material made available by the director of the school in Łużna, author's own collection. The results of the competition are taken from the Informator Gminny. Eużna, no. 2 (2015), p. 11, also interview with Kazimierz Krok.

Informator Gminny. Eużna, no. 3 (2015), p. 2.

82 Ibid., mentioned are the songs: Warszawianka, Marsz Pierwszej Brygady, Przybyli utani pod okienko and Pierwsza kadrowa. 
rienced by the soldiers as these songs had considerable significance for them. They not only belped them to fight for their Fatherland but also supported the soldiers during battle. By singing the hymns and songs of the soldiers, in our hearts and thoughts we could recall all of those who had given their lives for the Fatherland..$^{83}$

Those laid to rest in the cemetery did not have - however - one Fatherland. They had a number of them and none of them survived World War I in an unchanged form. What is more, it was from the ashes of those countries/empires that Poland emerged. And it was Poland which was praised and honoured by those Polish patriotic songs during the centennial celebrations. This paradox of history is expressed by the fact that the celebrations were held to mark the centenary of the battle in a cemetery designed to commemorate an Austro-Hungarian victory which had been expected in Vienna by the descendants of those who had won their independence at the expense of the fall of the Habsburg monarchy. As the head of the Łużna local authority, Kazimierz Krok, put it: Poles took part in this battle. Many of them fell on the battlefield. This battle contributed to the weakening of the Russian army which it never recovered from until the end of the war. It was the first step towards Polish freedom. ${ }^{84}$ The semantic content of this wartime lieu de mémoire - as can be seen - is tremendous.

The presence of a Polish, national significance during the centennial celebrations was alongside a supranational frame of reference. Furthermore, during the evening commemorations at the gontyna (1 May 2015), candles were placed on all of the graves. No grave was distinguished and none were omitted. The "Appeal for Freedom, the Appeal of the Fallen, and the prayers for the dead" were read and they were heard by young people from the Czech Republic, Hungary, Slovakia, Germany, France and Italy. ${ }^{85}$

In this part of the ceremony, the national aspect was clearly weakened or even disappeared. It was dominated by the transnational character of the battle itself. The departure from the national canons was reflected in the ecumenical prayer for the soldiers who were buried in the cemetery. Their surnames, ranks, nationalities or affiliation were not mentioned and, as a result, there was no absence of reflective words and questions as to the sense of millions of victims and the warning for the present and future generations. ${ }^{86}$ The warning stemming from this event did not have a national character and, what is more, it went beyond national lines and took on a universal significance and meaning.

83 Ibid., p. 3.

84 Interview with Kazimierz Krok.

85 Informator Gminny. Łużna, no. 3 (2015), p. 3. Łużna maintains contact with foreign partners. Looking after visitors from overseas schools to the cemetery is one form of this cooperation. The examples given refer to just such a visit.

Ibid., p. 4. 


\section{EUROPEAN HERITAGE LABEL - THE APPLICATION}

The commencement of work on the application for a European Heritage Label for cemetery no. 123 in Łużna-Pustki introduced this lieu de mémoire into new interpretative contexts, reflecting the political need for the implementation of Polish historical policy within the European Union. The local administration joined in with the preparations, but the provincial and government administrations played a crucial role. ${ }^{87}$ Finally, the Łużna application was supported by Polish experts and the Ministry of Culture and National Heritage. As a result, the symbolic formatting of this place of memory began which was to not only show the honour and victory of the multicultural and multireligious Austro-Hungarian Empire (which would have been in accordance with the intentions of its builders during World War I) or the Polish road to freedom but rather to connect itself to the values which are recognised as being important for European history and identity. ${ }^{88}$

To connect cemetery no. 123 in Łużna-Pustki with European values, one may indicate a particular part of the application where one can read that the values which formed the basis for the whole cemetery in World War I in West Galicia are still very much present in Europe and the European Union. To these common, unifying values are respect for human dignity, democracy, human rights, including the rights of minorities, and broadly understood pluralism. They also include the memory of those who has passed away, and recognition of cultural heritage and past art as concepts bonding societies and nations. ${ }^{89}$

The authors of the application emphasized above all the role played on the Eastern Front during World War I by the so called 'Gorlice Offensive' of the Austro-Hungarian and German army, which eventually held back the Russian army marching towards the west of Europe, shifting the front-line - until Brusilov's Offensive in June 1916 - several bundred kilometres to the east. The breakthrough on the front at the 'Little Verdun' - as the Battle of Gorlice is also known - came at great cost to both sides and, as a result of which, the Łużna-Pustki Cemetery no. 123 is divided into quarters, according to military affiliation, encompassing Austrian-Hungarian (912), German (65) and Russian (227) army soldiers of various nationalities. Furthermore, the [m]ajority of earth and construc-

87 Interview with Joanna Florkiewicz-Kamieniarczyk, and the interview with Kazimierz Krok.

European Heritage Label Application Form 2015, point "Criteria to be met by the candidate site", p. 11.

Ibid., subsection 1.3 "The place and role of the candidate site in European history and European integration, its links with key European events, personalities or movements", subsection 1.3 "The place and role of the candidate site in the development and promotion of the common values that underpin European integration", p. 12. It is worth noting that in the supporting material provided by the European Commission in relation to the European values which need to be displayed there is a reference to do: Article 2 of the Treaty on European Union states that 'the Union is founded on the values of respect for buman dignity, freedom, democracy, equality, the rule of law and respect for human rights, including the rights of persons belonging to minorities. The values are common to the Member States in a society in which pluralism, non-discrimination, tolerance, justice, solidarity and equality between women and men prevail.' The common values that underpin European integration are also described greater in detail in the Charter of Fundamental Rights of the European Union. 
tion works in both cemeteries was performed by war prisoners - mainly Russian ones. The application stressed the fact also that the Pustki necropolis is the largest wartime cemetery in IV District of $€ u \dot{z}$ a and one of the most important - in terms of propaganda and artistically - in the area of operation of the $O G W$ [War Graves' Department]. ${ }^{90}$

The international and artistic character of the cemetery was emphasised in the application by appealing to the art at the turn of the century that both of the creators of the Łużna necropolis were excellent representatives. In the application we can read that: [Jan] Szczepkowski preferred a classicist and historical form, without monumentalism, complemented with elements inspired by domestic art, particularly folk building and ornamental art. [Dušan] Jurkovic, on the other hand, drew inspiration from Vienna Secession and Wiener Werkstätte, the Arts and Crafts movement, and the Slovakian and Moravian folk art of Carpathian region. He was also a pioneer of open air ('Skansen') museums - he co-organised the second Europe's open air museum - the 'Vallachian Chamber' in Vsetin and 'Vallachian Village' exposition during ethnographic exhibition in Prague (1895).91

The unique artistic value of the site was stressed in the following manner: The monumental soldiers' necropolis, established with great effort already during the war, which makes it a unique place, is one of the most beautiful and important World War I cemeteries in Europe. ${ }^{92}$

The new, previously untried idea of uniting all of the fallen in a common place for both the victors and the vanquished is - of course - also mentioned in the application. The cemetery itself is presented as: a burial place where all soldiers, the winners and the defeated, were treated with equal respect regardless of the nationality, religion, or military affiliation and given the right to decent burial, the cemetery has all element of a site a symbol important for European history and identity. ${ }^{93}$ In this manner, the Eużna necropolis extends its range to that of an ecumenical place of rest.

This unifying message was provided with additional support by the local authority on the request of a panel of experts in Brussels. Particularly strongly stressed was the ecumenical character of the cemetery: It [Eużna cemetery] very clearly embodies the idea of ecumenism: identical treatment of winners and losers, independent of military, ethnic, and religious affiliation. It offers 'resting together in the same place' to soldiers who were reconciled in death. ${ }^{94}$

The heroism was also given another face: the fallen were showed equal respect here, out of consideration for human dignity, remembrance, and soldierly reconciliation af-

90 European Heritage Label Application Form 2015, point "Description of the site", p. 8. The abbreviation OGW stands for the Oddział Grobów Wojennych, Eng. War Graves' Department of Austro-Hungarian Military Headquarters.

91 European Heritage Label Application Form 2015, point “Description of the site”, p. 9.

92 European Heritage Label Application Form 2015, point "Criteria to be met by the candidate site", subsection 1.2 "The place and role of the candidate site in European history and European integration, its links with key European events, personalities or movements", p. 11.

93 European Heritage Label Application Form 2015, point "Criteria to be met by the candidate site", p. 11.

94 Additional material prepared for the panel of experts supplied by the Małopolska Provincial Office. 
ter death which ends all fight and hatred. All were given the right to rest in peace in the bosom of nature, as they all - having died in action - were heroes. ${ }^{95}$

The application procedure required the cemetery to be positioned according to essence and achievement of contemporary EU values: The Euzna-Pustki cemetery - as intended by its creators is a multi-national burial place, for over a century promoting the values cherished by the European Union, such as respect for human dignity, equality and brotherhood of people, reconciliation, and peace. ${ }^{96}$ The values which formed the basis of the cemetery are also to be found in those which are being achieved by the EU: They [the builders of the cemetery] tried to replace the chaos of the battlefield with harmony of art and nature; the noise of the battle - with poetry; fighting - with consolation; hatred with love. In this way they opposed the very essence of war, trying in this symbolic way to reverse its horrendous logic. These ideas are the foundations of the European civilisation and integration..$^{97}$

The cemetery in Łużna joins together in eternal rest: Catholics, Protestants, members of the Orthodox church, Orthodox Jews, Muslims, Austrians, Russians, Hungarians, Germans, Ukrainians, Jews, Poles, Czechs, Slovaks, Bosnians, and others. ${ }^{98}$ All had died a heroic death. The supranational character of the soldiers' sacrifice amounted to what all the fallen soldiers had in common: heroism, sacrifice for the home country, truthfulness to their soldier's oaths. ${ }^{99}$

The application faithfully reports the history of the forgotten cemetery in the 1920s: In the 1920s or 1930s, a single concrete gravestone was placed on one of the graves. Before World War II, some tidying-up work was conducted, consisting mainly in the replacement of rotting wooden crosses, improving the structure of the earth graves and taking care of the trees and other greenery. ${ }^{100}$ The document recalls the pilgrims who travelled to the burial place of the soldiers. The underlying assumption was that all Galician cemeteries after the war were to become pilgrimage destinations for families and friends as well as school trips, cared for by the reconciled European nations. ${ }^{101}$

95 European Heritage Label Application Form 2015, point "Criteria to be met by the candidate site", subsection 1.1 "The cross-border or pan-European nature of the candidate sites", p. 11.

96 European Heritage Label Application Form 2015, point "Relevance of the application", p. 10.

97 European Heritage Label Application Form 2015, point "Criteria to be met by the candidate site", subsection 1.2, p. 12.

98 European Heritage Label Application Form 2015, point "The place and role of the candidate site in European history and European integration, its links with key European events, personalities or movements", subsection 1.3, p. 12.

99 European Heritage Label Application Form 2015, point "Criteria to be met by the candidate site", subsection 1.2, pp. 11-12.

100 European Heritage Label Application Form 2015, point "Description of the site", p. 9.

101 European Heritage Label Application Form 2015, point "The place and role of the candidate site in European history and European integration, its links with key European events, personalities or movements", subsection 1.3 , p. 12 . 


\section{A EUROPEAN PRODUCT IN A LOCAL CONTEXT}

The entry of a fourth Polish place on to the list of those holding a European Heritage Label (EHL) is often presented as a 'success' of Polish historical policy in the European arena. ${ }^{102}$ This is also true at the local level, where in the Informator Gminny. Euzna once can read that this is a prestigious award and that presently there are 3 [other] objects in Poland which have a EHL. These are the Union of Lublin, the Gdansk Historical Shipyard and the Constitution of the $3^{\text {rd }}$ of May, making Poland the leader amongst states in Europe. ${ }^{103}$ Whilst it is difficult to deny this, the satisfaction with the (quantitative) achieved success is symptomatic of the perception of Europe as a space/arena in which various places (reported by national expert bodies in cooperation with local authorities and non-governmental associations) can compete with one another and the leader becomes the state that has - at least temporarily - the highest number of places

Fig.3. Page from the brochure prepared by the Local Authority of Łużna to mark the award of the European Heritage Label

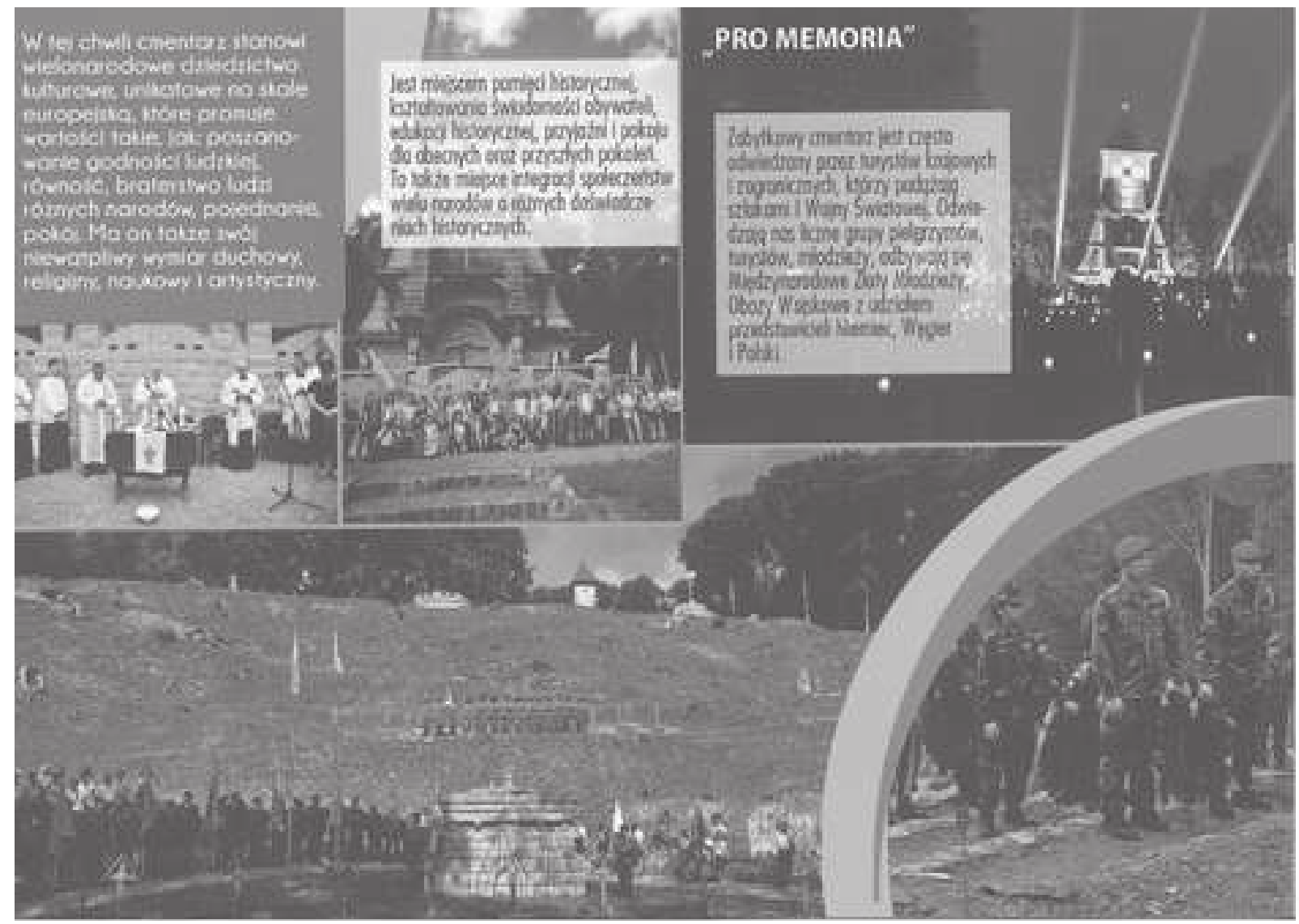

(C) photo: A. Ziobrowski, T. Machowski, D. Bugno, P. Sekuła; graphic design: T. Machowski, D. Bugno (C) Eużna Commune Office

102 See: interview with Joanna Florkiewicz-Kamieniarczyk, and the interview with Kazimierz Krok.

103 “Cmentarz wojenny nr 123 Łużna-Pustki nominowany do Znaku Dziedzictwa Europejskiego", Informator Gminny. Łużna, no. 6 (2015), p. 4. 
distinguished. In this context, the past is an area which is not so much complementary at European level, but rather a diplomatic strategy aimed at presenting an object as quickly as possible within the borders of a member state. This solution, from a purely pragmatic point of view, simply blocks the possibility of choosing similar places (within other countries) which may aspire to that distinction. The principle of the order and degree of preparation of the application - even if it isn't ideal - is, however, applied in practice in the classification, valorization and distinguishing of European heritage.

As a result, 'our' places of memory and 'our' interpretation of the past (even if it is only to apply to preselected places in the procedure application for a European Heritage Label) is heard, present and taken into account in the European arena. It is a practical expression of the historical policy conducted by a member state in the European arena.

\section{CONCLUSIONS}

It was not long ago that the war cemeteries of World War I were forgotten and today they have become a tool and hope for the development of the whole region. This has seen the transformation of heritage from a difficult and 'foreign' one into 'our' heritage which can be utilised; this is a story of 'orphaned' heroes whose Fatherland has vanished but another homeland - Europe? - has welcomed them into its hall of fame in the second decade of the $21^{\text {st }}$ century. ${ }^{104}$ This symbolic and discursive ${ }^{105}$ process is accompanied by an economic element, making the cemetery complex a factor in the development of the entire economy of the region. ${ }^{106}$ And in this new meaning, it is subject - like any piece of heritage - to classification, ${ }^{107}$ planning, utilization, management, etc. As a result, this 'heritage without heirs' has become a product of the European tourism market and historical pop culture.

The war cemetery no. 123 in Łużna-Pustki allows the identification of the multifarious nature of the resemiotization of this lieu de mémoire. It applies, amongst others, to the classical device of Pro Patria Mortuis, and which moves from a narrow frame of its national interpretation to enter the European. The cemetery itself becomes a means

104 On distinction between cultural goods and heritage see: A. Tomaszewski, "Europa Środkowa: dobra kultury a dziedzictwo kultury", in J. Purchla (ed.), Europa Środkowa - nowy wymiar dziedzictwa. Materiaty międzynarodowej konferencji zorganizowanej w dniach 1-2 czerwca 2001, Kraków 2002, pp. 133-134. On the subject of the theory of heritage and cultural goods see also: idem, "Dziedzictwo i zarządzanie", in K. Gutowska (ed.), Problemy zarzadzania dziedzictwem kulturowym, Warszawa 2000, pp. 7-11.

105 L. Smith, Uses of Heritage, London 2006; L. Smith , N. Akagawa (eds.), Intangible Heritage, London-New York 2009.

106 More information on the economic/tourist exploitation on cemetery no. 123 can be found in: Informator Gminny Eużna, no. 2-6 (2015); no. 1-4 (2016).

107 G.J. Ashworth, "Heritage in Fragments: A Fragmented Instrument for Fragmented Policies", in: M. Murzyn, J. Purchla (eds.), Cultural Heritage in the $21^{\text {st }}$ Century. Opportunities and Challenges, Kraków 2007, pp. 29-30. See also: B. Graham, G.J. Ashworth, J.E. Tunbridge, A Geography of Heritage. Power, Culture and Economy, London-New York 2000. 
which can be used by local and European politicians, managers, enthusiasts, NGO's etc. This imperial sacrum becomes a European symbol and/or rather a product of cultural policy. ${ }^{108}$

The memory present in the cemetery no. 123 in Łużna-Pustki is a subject of the Polish policy of memory in the European arena, which results in the top-down Europeanization of this particular lieu de mémoire. In this sense, the use of this cemetery is a specific response to the institutional and top-down needs of the European past/heritage/memory, which should be locally or nationally rooted but transnationally shared, felt, and valorized.

It is worth noting that the selection of the Eużna-Pustki cemetery for a place on the EHL list is a result of the synergy of what is locally valued and experienced as European heritage (the bottom-up perspective), and what experts from national and/or European level consider it to be (the top-down perspective). These two levels of use partially meet. The local use of EHL consists in particular in the building of a tourist brand of the region, while the European level is a space of historical policy pursued by the Polish government. In other words, the economic pragmatism of the local level and the use of the cemetery as a factor of economic development of the region coincides and complements the historical policy pursued by the Polish government in the EU arena.

One may connect this to the motto of the European Heritage Label that Europe starts here, only that - after Jan Józef Lipski - it seems that it should be stressed that Europe does not begin everywhere but precisely there where mutually inflicted suffering was overcome. This perspective not only takes into accounts our own suffering but what is most important - it does not overlook the sufferings of others. Lipski defined this as we must tell ourselves everything, on the condition that everyone will talk about their own guilt. Without this weight of the past, we will not be able to experience a common future. ${ }^{109}$

In this respect, the potential of the cemetery is exceptional and the European slogan Europe starts here finds its expression in the inscription written by Hans Hauptmann for the necropolis:

In life divided

Death has united

Noone knows their names

Friends and enemies

108 J. Purchla, "Management of Historical Cities and Market Forces. The Central European Experience", in idem (ed.), From the World of Borders to the World of Horizons, transl. by T. Bałuk-Ulewiczowa et al., Kraków 2001, pp. 99-111. Purchla wrote that: the heritage of Central European cities is not only something sacred but also a commodity - so this sphere also lies in the economic zone. This fact cannot be timidly concealed. The co-joining of artistic and intellectual potential of our historical cities, and the abandonment of the static model of protection are the most important lessons learned from our five-years' experience in transforming the reality of Central Europe (p. 109).

109 J.J. Lipski, “Odprężenie i pojednanie. Polemika z Gunterem Grassem”, in idem, Powiedzieć sobie wszystko... Eseje o sasiedztwie polsko-niemieckim, Gliwice-Warszawa 1996, pp. 89-90. 
Who they were, what they meant

Extinguished, passed on

All that remains

Is their loyalty. ${ }^{110}$

This inscription, nearly a century old, expresses a conviction about the great leveller which is death and finds a counterpart in the contemporary attempt to find in Europe such common, supranational, European places of memory where the memory of past tragic events is not only transmitted from generation to generation but also where its interpretation is guided by principles of unity and goes beyond the symbolic limes which divide those who won from those who were defeated.

In reference to the inscription mentioned above, one may claim that the memory present in the cemetery in Eużna is not completely free from the cultural context which gave birth to it and it is within this framework that it is undergoing constant and continual evolution. It is a classic and romantic image of the unknown (or known) soldierhero who has given their life for the Fatherland and in return has received the laurels of honour and glory, achieving eternal life in the memory of successive generations. ${ }^{111}$

In any reflection upon the cemetery in Łużna, the topos of 'Pro Patria Mortuis' cannot be avoided since it crops up and returns in different forms and permits the necropolis to be firmly anchored in the broader, European context. This mythical structure endures and at the European level it organizes around itself senses, symbols, narratives, objects, practices and rituals. The example of Łużna permits reflection on how mythical structures, which are firmly rooted in the national imagination, have the potential to organise another imagination at a different, supranational European level. The question of whether European heritage presented in this manner is more of a postulate than a socially experienced fact remains open. I am of the opinion that it is not a simple description of reality but has a deeply mythological character. And in that sense, it does not say how it is, but how it should be. And, for this reason, it has the character of a postulate and a moral signpost.

\section{BIBLIOGRAPHY}

Ashworth G.J., "Heritage in Fragments: A Fragmented Instrument for Fragmented Policies", in M. Murzyn, J. Purchla (eds.), Cultural Heritage in the $21^{\text {st }}$ Century. Opportunities and Challenges, Kraków 2007.

110 Inscription at no. 123 in Łużna-Pustki. A. Partridge, Otwórzcie bramy pamięci..., p. 226.

111 See: E. Kantorowicz, Mourir pour la patrie...; S. Czarnowski, Kult bohaterów...; M. Ossowska, Ethos rycerski..., pp. 7-20. Comp.: M. Janion, Wobec zta, Chotomów 1989; eadem, Goraczka romantyczna, Warszawa 1975; eadem, Do Europy - tak, ale razem z naszymi umartymi, Warszawa 2000. A separate element - which I will not explore here - is the mythologization of Galicia which stems from the manner of interpretation of the cemetery. 
Augé M., Non-lieux, introduction à une anthropologie de la surmodernité, Paris 1992.

Barthes R., Mythologies, Paris 1957.

Broch R., Hauptmann H., Zachodniogalicyjskie groby bohaterów z lat wojny światowej 1914-1915, transl. by H. Sznytka, ed. by J.J.P. Dragomir, Tarnów 1994 [Die Westgalizischen Heldengräber aus den Jabren des Weltkrieges 1914-1915, Wien 1918].

Chrudzimska-Uhera K., "O dylematach Polaka, artysty, żołnierza. Jan Szczepkowski jako projektant cmentarzy I wojny światowej”, in M. Łopata, K. Ruszała (eds.), Znaki pamięci IV w 95. rocznice bitwy gorlickiej. Materiaty z konferencji, Gorlice 2011.

Czarnowski S., Kult bohaterów i jego spoteczne podtoże. Święty Patryk - bohater narodowy Irlandii, transl. by A. Glinczanka, Warszawa 1956.

DiNardo R.L., Przetom. Bitwa pod Gorlicami-Tarnowem 1915, transl. by J. Szkudliński, Poznań 2012.

Drogomir J.J.P., Polegli w Galicji Zachodniej 1914-1915 (1918). Wykaz polegtych i zmartych pochowanych na 400 cmentarzach wojskowych Galicji Zachodniej, vol. 1, Tarnów 1999.

Drogomir J.J.P., "Wstęp do wydania polskiego", in R. Broch, H. Hauptmann, Zachodniogalicyjskie groby bohaterów z lat wojny światowej 1914-1915, transl. by H. Sznytka, ed. by J.J.P. Dragomir, Tarnów 1994 [Die Westgalizischen Heldengräber aus den Jahren des Weltkrieges 1914-1915, Wien 1918].

Duda O., Cmentarze w Galicji Zachodniej 1914-1918, Warszawa 1995.

Dziedziak M., "Niezrealizowane projekty cmentarzy wojennych Dušana Jurkoviča w Beskidzie Niskim", in M. Dziedziak (ed.), Znaki pamięci. Materiaty z konferencji naukowej, Gorlice 27.10.2007, Gorlice 2007.

Erickson E.J., Gallipoli i Bliski Wschód 1914-1918. Od Dardaneli do Mezopotamii, transl. by J. Kozłowski, Poznań 2011.

Frodyma R., Cmentarze wojskowe z okresu I wojny światowej w rejonie Beskidu Niskiego i Pogórza, Warszawa 1989.

Graham B., Ashworth G.J., Tunbridge J.E., A Geography of Heritage. Power, Culture and Econo$m y$, London-New York 2000.

Horace, Odes III, 2.

Informator Gminny. Łużna, no. 2-6 (2015); no. 1-4 (2016).

Janion M., Do Europy - tak, ale razem z naszymi umartymi, Warszawa 2000.

Janion M., Goraczka romantyczna, Warszawa 1975.

Janion M., Wobec zta, Chotomów 1989.

Jordan D., Batkany, Wtochy i Afryka 1914-1918. Od Sarajewa do Piawy i Jeziora Tanganika, transl. by J. Szkudliński, Poznań 2011.

Jordan D., Neiberg M.S., Front Wschodni 1914-1920. Od Tannenbergu do wojny polsko-bolszewickiej, transl. by J. Kozłowski, Poznań 2010.

Jordan G., Weedon C., Cultural Politics. Class, Gender, Race and the Postmodern World, Oxford 1995.

Kantorowicz E., Mourir pour la patrie et autres textes, Paris 1984.

"Kaplica cmentarna (gontyna), Wzgórze Pustki w Łużnej. Dzieje historyczne - czasy I Wojny Światowej", Cmentarz wojenny Nr 123 Łużna-Pustki (official website devoted to cemetery no. 123 in Łużna-Pustki), at <http://www.pustki.luzna.pl/gontyna.html>. 
Klimecki M., Gorlice 1915, Warszawa 1991.

Kosiński W., "Wstęp”, in A. Partridge, Otwórzcie bramy pamięci. Cmentarze wojenne z lat 1914-1918 w Matopolsce, Kraków 2005.

Kroh A., "Dušan Jurkovič a styl zakopiański", in Cmentarze z I wojny światowej na Podkarpaciu. Materiaty z sesji krajoznawczej, Wysowa 23-25 października 1987, Warszawa 1989.

Lipski J.J., "Odprężenie i pojednanie. Polemika z Gunterem Grassem”, in J.J. Lipski, Powiedzieć sobie wszystko... Eseje o sasiedztwie polsko-niemieckim, Gliwice-Warszawa 1996.

Łaptos J., Solarz J., Zgórniak M., Wielkie wojny XX wieku (1914-1945), Warszawa 2006.

Łopata M., "Groby żydowskich żołnierzy Wielkiej Wojny w Galicji”, in M. Dziedziak (ed.), Znaki pamięci. Materiaty z konferencji naukowej, Gorlice 27.10.2007, Gorlice 2007.

Nykiel B., "Cmentarze wojenne Twierdzy Kraków z okresu I wojny światowej", in W. Frazik et al. (eds.), Przez dwa stulecia XIX i XX w. Studia historyczne ofiarowane prof. Wactawowi Felczakowi, Kraków 1993.

Olszański T.A. (ed.), Pierwsza wojna światowa w Karpatach, Warszawa 1985.

Ossowska M., Ethos rycerski i jego odmiany, Warszawa 1986.

Pajewski J., Pierwsza wojna światowa 1914-1918, Warszawa 2004.

Partridge A., Otwórzcie bramy pamięci. Cmentarze wojenne z lat 1914-1918 w Matopolsce, Kraków 2005.

Purchla J., "Management of Historical Cities and Market Forces. The Central European Experience", in J. Purchla (ed.), From the World of Borders to the World of Horizons, transl. by T. Bałuk-Ulewiczowa et al., Kraków 2001.

Ruszała K., "Zachodniogalicyjskie cmentarze na pocztówkach wydanych przez Oddział Grobownictwa Wojennego. Projekty i ich realizacja”, in M. Dziedziak (ed.), Znaki pamięci. Materiaty z konferencji naukowej, Gorlice 27.10.2007, Gorlice 2007.

Sanocka B., VIII Matopolskie Dni Dziedzictwa Kulturowego, Kraków 2006.

Schubert J., Austriackie cmentarze wojenne w Galicji z lat 1914-1918, Kraków 1992.

Schubert J., "Organizacja grobownictwa wojennego w Monarchii Austro-Węgierskiej. Dziewiąty Wydział Grobów Wojennych (Kriegsgräber-Abteilung) przy Ministerstwie Wojny - powstanie i działalność w latach 1915-1918. Organization and Structure of Wartime Cemeteries in Austro-Hungarian Monarchy. The IX War Graves Division (Kriegsgräber-Abteilung) at the War Ministry in Vienna in the Years 1915-1918", Architektura. Czasopismo Techniczne. Architecture. Technical Transactions, no. 13 (2009).

Showalter D.E., Tannenberg 1914. Zderzenie imperiów, transl. by R. Dymek, Białystok 2005.

Smith L., Uses of Heritage, London 2006.

Smith L., Akagawa N. (eds.), Intangible Heritage, London-New York 2009.

Tomaszewski A., "Dziedzictwo i zarządzanie”, in K. Gutowska (ed.), Problemy zarządzania dziedzictwem kulturowym, Warszawa 2000.

Tomaszewski A., "Europa Środkowa: dobra kultury a dziedzictwo kultury", in J. Purchla (ed.), Europa Środkowa - nowy wymiar dziedzictwa. Materiaty międzynarodowej konferencji zorganizowanej w dniach 1-2 czerwca 2001, Kraków 2002.

Winter J., Sites of Memory, Sites of Mourning. The Great War in European Cultural History, Cambridge 2008. 
"Znak Dziedzictwa Europejskiego" (European Heritage Label), Ministerstwo Kultury i Dziedzictwa Narodowego (Ministry of Culture and National Heritage), at <http://www. mkidn.gov.pl/pages/strona-glowna/wspolpraca-z-zagranica/znak-dziedzictwa-europejskiego.php>.

\section{Interviews with}

Joanna Florkiewicz-Kamieniarczyk, director, Department of the Conservation of Monuments of Kraków and National Heritage, Małopolska Provincial Office in Kraków, 4 April 2016. Kazimierz Krok, head of the Eużna local authority, 7 April 2017.

\section{Conversation with}

Zofia Żmijowska, a Polish teacher at the school in Łużna and amateur photographer, 20 April 2017.

\section{Graphic material}

Map prepared by the Małopolska Institute of Culture for the $8^{\text {th }}$ edition of the Małopolska Heritage Days (20-21 May 2006).

\section{Other materials}

Application made to the Ministry of Culture and National Heritage and by the Department of the Conservation of Monuments of Kraków and National Heritage, Małopolska Provincial Office in Kraków and the local authority of Łużna.

Documentation for the photographic competition entitled "Międzygminny Konkurs Fotograficzny". 100 ${ }^{\text {th }}$ Anniversary of the Battle of Gorlice (version for primary and junior high schools), material made available by the director of the school in Łużna, author's own collection.

Regulations of the Historical Knowledge Competition. 100 Gorlice, material made available by the director of the school in Łużna, author's own collection.

Regulations of the Regional Photographic Competition. $100^{\text {th }}$ Anniversary of the Battle of Gorlice (version for primary and junior high schools), material made available by the director of the school in Łużna, author's own collection. 
Krzysztof KOWALSKI holds an MA degree in ethnology from the Jagiellonian University in Kraków (1993), a PhD in history from the same university (2000) and a Master of Public Administration (2004, double degree programme) from the University of Economics in Kraków and Copenhagen Business School. He works and teaches in the Department of European Heritage of the Institute of European Studies at the Jagiellonian University. His specialization is the theory of heritage and anthropology of Europe. During his academic career he has received many scholarships (including those from the Swiss government, Stefan Batory Foundation, Swedish Institute). He had a postdoctoral position in the Centre for European Studies at Lund University (2015) and has frequently been a visiting professor at l'Institut d'Etudes Politiques in Strasbourg as well as in Lyon (2015). He wrote $O$ istocie dziedzictwa europejskiego rozważania (Kraków 2013) and co-edited with Barbara Törnquist-Plewa The Europeanization of Heritage and Memories in Poland and Sweden (Kraków 2016). 